\title{
Erratum to: A testing cascade for the detection of genetically modified rice by real-time PCR in food and its application for detection of an unauthorized rice line similar to KeFeng6
}

Ralf Reiting · Lutz Grohmann • Dietrich Mäde

Published online: 7 April 2010

(C) Springer Basel AG 2010

Erratum to: J Verbr Lebensm

DOI 10.1007/s00003-010-0573-3

Unfortunately an uncorrected version of Fig. 1 has been published. You can find the correct figure below.

The online version of the original article can be found under doi:10.1007/s00003-010-0573-3.

Dr. R. Reiting (ه)

Hessisches Landeslabor, Druseltalstr. 67,

34131 Kassel, Germany

e-mail: Ralf.Reiting@lhl.hessen.de

Dr. L. Grohmann

Bundesinstitut für Verbraucherschutz

und Lebensmittelsicherheit, Mauerstr. 39-42,

10117 Berlin, Germany

Dr. D. Mäde

Landesamt für Verbraucherschutz,

Freiimfelder Str. 68, 06112 Halle (Saale), Germany 


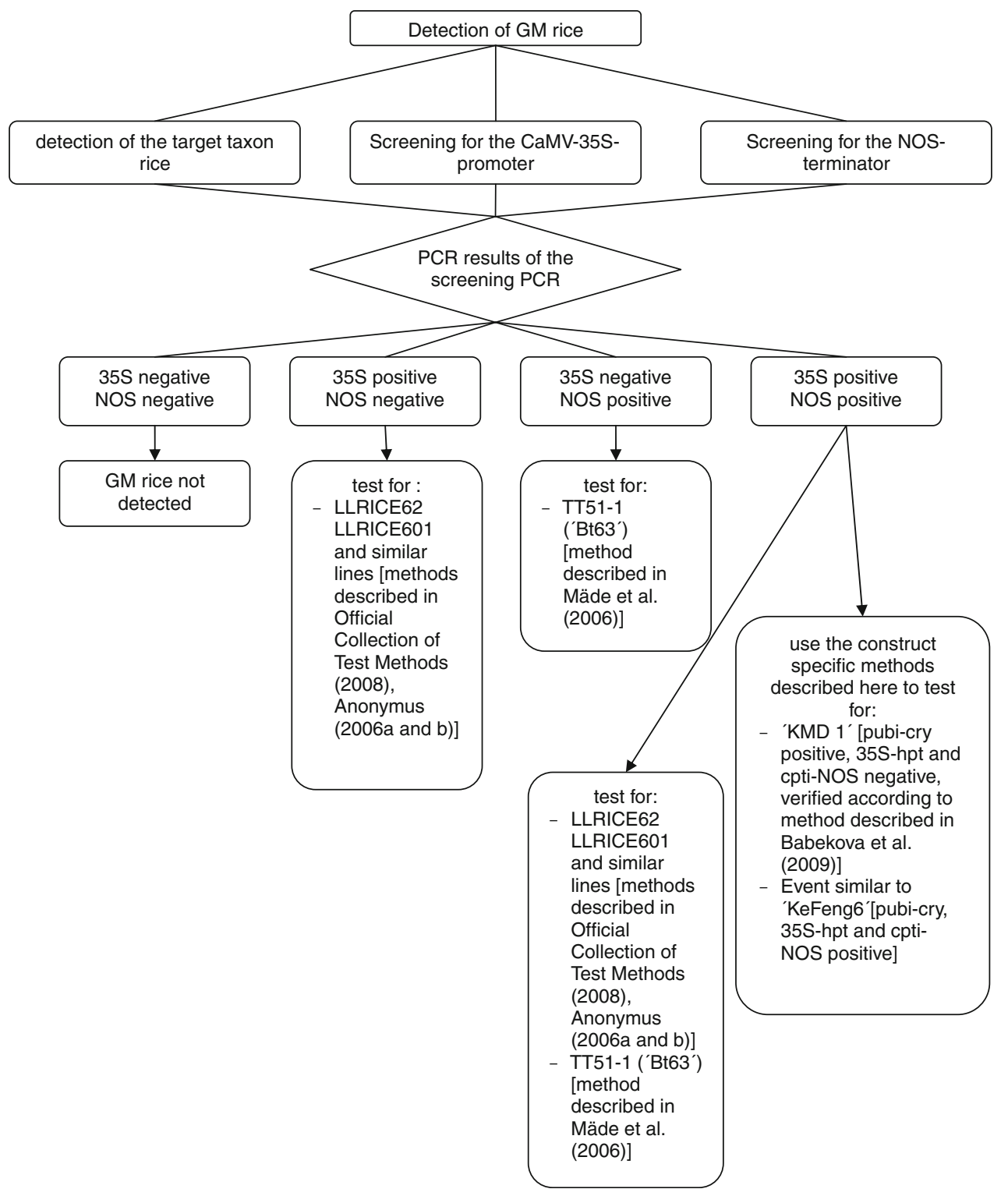

